St udia P hiloso phic a

Wr a t i s l a vi e n s i a

vol. XVI, fasc. 3 (2021)

https://doi.org/10.19195/1895-8001.16.3.6

MAREK SIKORA

ORCID: 0000-0002-9451-8278

Politechnika Wrocławska

\title{
Struktura rewolucji relatywistycznej i kwantowej w fizyce, czyli o systematyczności badań naukowych i roli kantyzmu we współczesnej filozofii nauki*
}

The structure of the relativistic and quantum revolution in physics. On the systematic nature of scientific research and the role of Kantian philosophy in contemporary philosophy of science

\begin{abstract}
The article is a voice in the discussion on Wojciech Sady's book Struktura rewolucji relatywistycznej i kwantowej $w$ fizyce [The Structure of Relativistic and Quantum Revolution in Physics]. The author points out that the central idea of this book directly refers to the works of Thomas Kuhn, who emphasized the role of revolutions in the process of scientific development. Sady criticizes this position, claiming that the development of science is primarily determined by systematic research. The author also argues with Sady's thesis that an important consequence of the relativistic and quantum revolution in physics is the fundamental questioning of the value of Kant's philosophy. The text tries to show that Kantism is still present in contemporary philosophy of science.
\end{abstract}

Keywords: Wojciech Sady, Thomas Kuhn, Kantism, scientific revolution

* Tekst zawiera uwagi na temat wybranych fragmentów książki prof. Wojciecha Sadego pt. Struktura rewolucji relatywistycznej $i$ kwantowej $w$ fizyce. Uwagi te ograniczają się tylko do tych tez książki, które mają charakter filozoficzny. 
Książka Wojciecha Sadego zatytułowana Struktura rewolucji relatywistycznej $i$ kwantowej w fizyce jest próbą wyjaśnienia przebiegu obu wskazanych w tytule rewolucji, które na przełomie XIX i XX wieku w sposób zasadniczy zmieniły sposób opisu natury rzeczywistości fizycznej. Autor pyta wprost: ,,jak to się stało, że - wbrew przymusom myślowym narzucanym przez mechanikę klasyczną — wymyślono teorię względności i mechanikę kwantową?"1. Udzielając odpowiedzi na to pytanie, wyraża krytyczne stanowisko wobec obrazu rozwoju nauki przedstawionego w klasycznej już pracy Thomasa S. Kuhna Struktura rewolucji naukowych. Swoją argumentację opiera na rzetelnej analizie materiału historycznego.

Sady twierdzi, że zasadniczym błędem Kuhna było to, iż porównywał on tylko stany wiedzy odległe w czasie, ignorując pośrednie stadia rozwoju teoretycznego ${ }^{2}$. Tymczasem badania naukowe w zakresie fizyki, jak pisze, charakteryzują się wielką systematycznością. Po pierwsze, polega ona na tym, by w każdej dziedzinie zaczynać badania od zjawisk najprostszych. Po drugie, wymaga, by

przeprowadzać zawsze wiele eksperymentów, w których te same obiekty lub rodzaje obiektów występują w rozmaitych konfiguracjach - co pozwala przypisać im odpowiednie własności teoretyczne, a także uwiarygadnia uzyskane rezultaty. $\mathrm{W}$ miarę zdobywania wiedzy $\mathrm{w}$ danej dziedzinie przechodzi się, krok po kroku, do badań nad zjawiskami bardziej złożonymi. [...] Uściśla się wszelkie wartości już zmierzone, a do obliczeń wprowadza się, w miarę postępu badań, kolejne poprawki. Jeśli udanie zbadano pewne obiekty czy procesy, podejmuje się podobne badania dotyczące obiektów czy procesów tamte przypominających ${ }^{3}$.

Szczególnie ważną funkcją systematyczności, podkreśla Sady, jest to, by wyeliminować z procesu rozwoju wiedzy kategorię szczęśliwego przypadku. Niekiedy przywołuje się na przykład opinie, że promienie X czy penicylina zostały odkryte właśnie za sprawą szczęśliwego przypadku. Takie opinie są jednak mylące, ponieważ pomija się w nich założenie, że warunkiem dokonania tego typu odkryć jest obecność odpowiednio przygotowanego umysłu badacza, który potrafi rozpoznać, że mamy do czynienia z czymś, co nie mieści się w ramach zastanego obrazu świata. Ponadto systematyczność badań przesądza o tym, że w pewnych sytuacjach niedokonanie odkrycia powinno się określić mianem (niefortunnego) przypadku ${ }^{4}$.

Rzetelna analiza procesu rozwoju fizyki pokazuje zatem, przekonuje Sady, że badacze krok po kroku odkrywają prawa przyrody, ponieważ są one esencjalną częścią właściwej fizyki, która opisuje wewnętrzną strukturę realnego świata. W takim ujęciu fizyka jest wyrazem bezinteresownego dążenia do klasycznie rozumianej prawdy. Bardzo mocnym argumentem na rzecz tej tezy jest przedstawiona w rozdziale ósmym książki idea o ewentualnej możliwości rozdwojenia naszego świata i powstanie dwóch odizolowanych od siebie światów, które podlegałyby tym samym prawom i zaczynałby swoją historię od tych samych warunków początkowych. Czy fizyka (oraz inne nauki), pyta Sady, rozwijałyby się w obu tych światach w podobny sposób? W odpowiedzi czytamy, że

\footnotetext{
1 W. Sady, Struktura rewolucji relatywistycznej i kwantowej w fizyce, Kraków 2020, s. 26.

2 Ibidem, s. 13.

3 Ibidem, s. 26.

4 Ibidem.
} 
w pewnych sytuacjach rozwój fizycznego obrazu świata, w obliczu dokonanych odkryć eksperymentalnych, jest zdeterminowany: wiedza zastana i wyniki eksperymentów decydują o tym, jakie nowe twierdzenie zostaje dodane do systemu. [...] Studia nad historią fizyki w naszym świecie sugerują więc, że we wspomnianych wyżej światach równoległych — jeśli wziąć pod uwagę odpowiednio długi czas rozwijałaby się ona w podobny sposób ${ }^{5}$.

Warto zwrócić uwagę na występujące w cytacie pojęcie „naszego świata”. Prowadzi ono wprost do sporu o realizm naukowy. Spór ten należy bez wątpienia do jednego z głównych zagadnień współczesnej filozofii nauki. Obecne w nim punkty widzenia zostały przedstawione jeszcze w pierwszej połowie XX wieku. Dyskusja między uczestniczącymi w sporze stronami nasiliła się pod koniec wieku XX i na początku XXI. Do sporu odnosili się niemal wszyscy przedstawiciele współczesnej filozofii nauki. Dlatego myślę, że przywołanie tego sporu w kontekście rozważań związanych z problemem rewolucji relatywistycznej i kwantowej w fizyce można uznać za uzasadnione ${ }^{6}$.

Spór o realizm naukowy sprowadza się w gruncie rzeczy do pytania o status poznawczy przedmiotów teoretycznych postulowanych przez teorie naukowe - na przykład elektronów, protonów czy kwarków. Zwolennicy realizmu naukowego przekonują, że przedmioty te istnieją w taki sposób, w jaki mówią o nich odpowiadające im teorie. Teorie takie mogą być oceniane pod względem prawdziwości bądź fałszywości ${ }^{7}$. Krytycy realizmu naukowego, czyli antyrealiści naukowi, przekonuja natomiast, że teorie naukowe nie są czymś, co samo w sobie reprezentuje pozajęzykowe obiekty realne. Nie są one też czymś, co może być prawdziwe lub fałszywe. Teorie są raczej czymś w rodzaju narzędzi, które umożliwiają wyprowadzanie zdań o tym, co obserwowalne ${ }^{8}$. Według antyrealistów realistyczna interpretacja mechaniki kwantowej prowadzi do nieakceptowalnych antynomii. Żadna głęboka rzeczywistość kwantowa, żaden świat elektronów i fotonów, twierdzi Bohr, w ogóle nie istnieje. Rzeczywisty jest jedynie sporządzony w tych terminach opis świata - mechanika kwantowa tworzy formalizm, dzięki któremu możemy przewidywać i wpływać na zdarzenia opisane w języku potocznym bądź w języku fizyki klasycznej. Zwodniczy byłby zatem postulat istnienia jakiejś odpowiadajacej temu formalizmowi rzeczywistości ${ }^{9}$.

Na potrzebę uwzględnienia sporu o realizm naukowy w świetle dociekań autora Struktury rewolucji relatywistycznej $i$ kwantowej $w$ fizyce warto, jak sądzę, zwrócić uwagę przede wszystkim ze względu na zawarte już we wstępie książki przekonanie, że

na przełomie XIX i XX wieku w fizyce doszło do dwóch rewolucji. Mechanika klasyczna została zastąpiona teorią względności z jednej, a mechaniką kwantową z drugiej strony [...]. Upadek mechaniki klasycznej zmienił raz na zawsze nasze pojmowanie natury wiedzy ludzkiej. Jeśli o filozofię chodzi, to

\footnotetext{
5 Ibidem, s. 214.

6 Szczególnie wtedy, gdy bierzemy pod uwagę to, że Niels Bohr, był — w przeciwieństwie do Alberta Einsteina — zwolennikiem antyrealistycznej interpretacji mechaniki kwantowej.

7 E. Nagel, Struktura nauki, tłum. J. Giedymin et al., Warszawa 1961, s. 112.

8 M. Dummett, Logiczna podstawa metafizyki, tłum. W. Sady, Warszawa 1998, s. 14.

9 S. Blackburn, Oksfordzki słownik filozoficzny, tłum. C. Cieśliński et al., Warszawa 2004, s. 173.
} 
klasyczny empiryzm, klasyczny racjonalizm, a także kantyzm odeszły do lamusa. Na znaczeniu, rzecz jasna zyskał relatywizm ${ }^{10}$.

To jednoznacznie brzmiące stanowisko wywołuje kilka ważnych z punktu widzenia filozofii nauki wątpliwości. Jedna z nich dotyczy przekonania, że klasyczny empiryzm i klasyczny racjonalizm odeszły do lamusa już po sformułowaniu krytycznej filozofii Immanuela Kanta. Krytyka obu doktryn stała się podstawą wyrażonego w Krytyce czystego rozumu rozróżnienia między tym, co rzeczywiste (realne) w sensie ontologicznym i tym, co rzeczywiste (realne) w sensie epistemologicznym. Rozróżnienie to w sporze o realizm naukowy można wskazać wtedy, kiedy w jego ramach wyodrębnimy realizm ontologiczny i epistemologiczny. Realizm ontologiczny (według Kanta - empiryczny) zakłada, że większość fizycznych obiektów zdroworozsądkowych i naukowych istnieje w sposób obiektywny (realny) niezależnie od władz poznawczych poznającego podmiotu. Antyrealizm ontologiczny uznaje natomiast zależność istnienia przedmiotów poznania od władz poznawczych poznającego podmiotu. Realizm epistemologiczny przyjmuje, że to, co poznajemy (czyli przedmioty poznania, wśród których są także przedmioty nieobserwowalne), jest niezależne (realne) od aktywności poznawczej poznającego podmiotu. Antyrealizm epistemologiczny uznaje natomiast zależność przedmiotów poznania od aktywności poznawczej ${ }^{11}$.

Uważam, że na pytanie o status poznawczy wytworów współczesnej nauki najbardziej przekonującej odpowiedzi udzielimy wtedy, gdy sformułujemy stanowisko, które jest syntezą realizmu ontologicznego i antyrealizmu epistemologicznego. Zwolennicy tego stanowiska utrzymują, że obiekty rzeczywiste, które bada nauka, moga być dane jedynie w postaci obiektu skonceptualizowanego, gdyż nie mamy bezpośredniego, czyli niezapośredniczonego przez aparat pojęciowy, dostępu do pozapodmiotowej rzeczywistości. Możemy więc co najwyżej porównywać ze sobą różne konceptualizacje ze względu na ich stosunek do empirycznych danych, które są przejawem realnie istniejącej rzeczywistości. Akceptacja antyrealizmu epistemologicznego nie wyklucza zatem możliwości równoczesnego opowiedzenia się za taką wersją realizmu ontologicznego, którą wskazałem w pewnym sensie za Kantem. Możemy bowiem z jednej strony przyjąć, że to, co poznajemy, nie jest niezależne od naszych władz poznawczych, z drugiej zaś możemy opowiedzieć się za takim realizmem ontologicznym, który nie zaprzecza istnieniu niezależnych od naszych władz poznawczych obiektów.

Akceptacja opinii o istnieniu niezależnych od naszych władz poznawczych obiektów nie pociąga jednak za sobą zgody na uznanie możliwości formułowania prawomocnych wypowiedzi, które dotyczą poznawczego statusu tych obiektów.

Wszystko, co wiemy, jak pisze Stefan Amsterdamski, wiemy jako ludzie. Żaden ponadludzki punkt widzenia nie jest możliwy. Treść naszej wiedzy naukowej uwarunkowana jest zarówno przez przedmiot badany, jak i przez inne czynniki, których wpływ jest dla poznania konstytutywny i którego epi-

10 W. Sady, Struktura rewolucji relatywistycznej $i$ kwantowej $w$ fizyce, s. 7.

11 Por. m.in. P. Horwich, Three Forms of Realism, „Synthese” 51 (1982), s. 121-202; T. Szubka, Antyrealizm semantyczny. Studium analityczne, Lublin 2001, s. 22-91; czy J. Woleński, Metamatematyka a epistemologia, Warszawa 1993, s. 285-286. 
stemologia nie może nadal pomijać. Uprzywilejowana sytuacja epistemologiczna nie jest możliwa, co nie znaczy, że wszystkie sytuacje epistemologiczne są równie uzasadnione: nie wszystko bowiem jest możliwe, przedmiot badany narzuca ograniczenia ludzkim zamiarom i niekiedy je niweczy. Kantowska koncepcja wiedzy apriorycznej okazać może się w zasadzie słuszna, o ile uznamy, iż „a priori” nie ma charakteru transcendentalnego, lecz wyznaczone jest na przykład przez czynniki biologiczne, historyczne i społeczno-kulturowe ${ }^{12}$.

Inna wątpliwość, która wiąże się ze wspomnianym już przekonaniem o przejściu kantyzmu do lamusa, dotyczy koncepcji stylu myślenia Ludwika Flecka. Uznając słuszność tej koncepcji, Sady za Fleckiem przypomina, że „myślenie jest czynnością zbiorową [...]. Produktem jego jest pewien obraz, widoczny tylko dla tego, kto w tej czynności zbiorowej bierze udział, lub myśl jasna również tylko dla członków kolektywu. Co myślimy i jak widzimy zależy od kolektywu myślowego, do którego należymy"13. Uważam, że w koncepcji stylu myślenia Flecka, podobnie jak w innych tego typu koncepcjach, wśród których można wyróżnić: koncepcję stylu myślenia Alistaira Crombiego, koncepcję stylu rozumowania Iana Hackinga, koncepcję „ideału wiedzy naukowej" Stefana Amsterdamskiego czy koncepcję epistemicznego układu odniesienia Kazimierza Jodkowskiego, przyjmuje się jedną wspólną zasadniczą tezę, że naukowy sposób ujęcia danego w doświadczeniu przedmiotu badań nie jest niezależny od założeń, które do nauki nie należą, ale bez nich nauki nie da się uprawiać.

Ta wspólna dla Flecka, Crombiego, Hackinga, Amsterdamskiego czy Jodkowskiego teza czerpie swoje inspiracje z filozofii Kanta. Hacking mówi o tym wprost, kiedy charakteryzuje swoją koncepcję stylu rozumowania, odnosząc ją do koncepcji stylu myślenia Flecka i Crombiego. Pisze, że są to koncepcje będące w pewnym stopniu kontynuacją podjętego w Krytyce czystego rozumu projektu wyjaśnienia możliwości istnienia obiektywnego doświadczenia. Rozsądek, który konstytuuje to doświadczenie, Hacking traktuje jednak, odmiennie niż Kant, jako wytwór historyczny i kolektywny ${ }^{14}$. Nawiązujacc do prac Crombiego, kanadyjski filozof nauki przekonuje, że analiza europejskiej tradycji uprawiania nauki i stosowanych w ramach tej tradycji metod wskazuje na występowanie sześciu różnych stylów naukowego rozumowania: (1) metody aksjomatycznej, charakterystycznej dla starożytnych matematyków; (2) eksperymentalnej eksploracji i pomiaru złożonych, dających się wykryć relacji; (3) modelowania hipotetycznego; (4) porządkowania tego, co różnorodne poprzez porównywanie i taksonomie; (5) statystyczne analizy regularności w populacjach oraz rachunek prawdopodobieństwa i (6) historyczne analizy genetycznego rozwoju. Listy tej nie należy traktować, podkreśla Hacking, jako zamkniętej i wskazuje na możliwość łączenia różnych stylów i tworzenia w ten sposób nowego stylu. Na przykład połączenie stylów (2) i (3) prowadzi do powstania czegoś, co można nazwać stylem laboratoryjnym. Styl ten ,charakteryzuje się konstruowaniem aparatury w celu tworzenia zjawisk, w odniesieniu do których hipotetyczne modele mogą być prawdziwe

12 S. Amsterdamski, Filozofia nauki i socjologia wiedzy, [w:] Racjonalność wspótczesności, H. Kozakiewicz, E. Mokrzycki, M. Siemek (red.), Warszawa 1992, s. 325.

13 W. Sady, Struktura rewolucji relatywistycznej i kwantowej w fizyce, s. 19.

14 I. Hacking, "Style" for historians and philosophers, [w:] idem, Historical Ontology, Cambridge-London 2002, s. 180-181. 
lub fałszywe, lecz przy wykorzystaniu innej płaszczyzny modelowania, a dokładnie modelów tego, jak działa sama aparatura i instrumenty"15.

Hacking zdecydowanie broni tezy o występowaniu odmiennych stylów naukowego rozumowania. Twierdzi, że każdy z nich zawiera własne kanony myślenia, każdy wnosi nowe standardy rozumowania, co szczególnie ważne, każdy wprowadza nowe kryteria ustalania tego, co ma być w ramach danego stylu prawdą i fałszem. Uczeni, którzy pozostają w obrębie tego samego stylu, mogą mieć odmienne zdanie na temat wartości logicznej jakiegoś sądu, ale zgodzą się na to, że ów sąd jest prawdziwy lub fałszywy. Założenie o istnieniu różnych stylów naukowego rozumowania nie prowadzi jednak, zastrzega Hacking, do subiektywizmu ani relatywizmu, albowiem ono nie implikuje sądu, że pewne twierdzenie o treści niezależnej od określonego stylu może być uznane za prawdziwe lub fałszywe ze względu na sposób rozumowania, który akceptujemy. Ponadto twierdzenia przyjęte obiektywnie jako prawdziwe pozostają tak określone przez styl naukowego rozumowania, którego nie można uzasadnić z zewnątrz. „Styl nie jest układem, który staje przed obliczem rzeczywistości"16. Odkrycia, które pojawiają się w naszej tradycji uprawiania nauki, stają się obiektywne dlatego, ,,̇̇e stosowane przez nas style rozumowania wyznaczają to, co zostaje uznane za obiektywność"17. Każdy styl wprowadza specyficzną dla siebie klasę obiektów, takich na przykład jak abstrakcyjne obiekty matematyczne, nieobserwowalne byty teoretyczne lub klasyfikacje biologiczne. To wiąże się z wprowadzaniem nowych praw i nowych modalności.

Hacking dopuszcza sytuację braku porozumienie między badaczami, którzy należą do różnych stylów naukowego rozumowania. Brak porozumienia między badaczami będzie wynikał z tego, że sposoby formułowania i obrony argumentów będą w obu przypadkach zasadniczo odmienne ${ }^{18}$. Aby badacz mógł zrozumieć argumenty występujące w innym stylu naukowego rozumowania niż ten, w którym sam się porusza, musi po prostu nauczyć się tego innego stylu. Warunkiem orzekania o prawdzie lub fałszu w obrębie danego stylu jest zrozumienie tego stylu od wewnątrz.

Autor Historical Ontology przestrzega jednak, by pamiętać, że kiedy mówimy o stylach naukowego rozumowania, to bierzemy pod uwagę style, których przedmiotem zainteresowania nie jest to, co zdroworozsądkowe, potoczne, obserwacyjne. Pozostając na takim przednaukowym poziomie, możemy orzekać o prawdzie i fałszu bez znajomości jakiegokolwiek stylu. Hacking mówi w takim przypadku o wypowiedziach, które mają charakter zmysłowy ${ }^{19}$.

Pisząc o swojej koncepcji ideałów wiedzy i funkcjach, jakie one pełnią, Stefan Amsterdamski zwraca uwagę, że ideały te między innymi wraz z akceptowanymi przez badaczy przekonaniami ontologicznymi i epistemologicznymi „współwyznaczają reguły akceptacji twierdzeń i ich odrzucania, zasady zadowalającego

\footnotetext{
15 Ibidem, s. 184.

16 I. Hacking, Language, truth, and reason, [w:] idem, Historical Ontology, s. 175 (kursywa zgodnie z orginałem).

17 Ibidem, s. 160-161. Można zatem mówić nie tyle o obiektywności w ogóle, ile „obiektywności lokalnej", czyli takiej, która dotyczy określonego stylu naukowego rozumowania.

18 Ibidem, s. 170.

19 Ibidem, s. 176.
} 
wyjaśniania zjawisk, sposoby budowania teorii — jednym słowem, reguły metodologiczne badań”20. Ponadto ideały wiedzy ,implikują określony etos naukowy i wewnętrzną organizację społeczności uczonych, ich rozumienie nauki jako instytucji społecznej" 21 .

W swojej koncepcji epistemicznego układu odniesienia Kazimierz Jodkowski akcentuje znaczenie szeregu najogólniejszych założeń na temat tego, jak można i jak nie można uprawiać nauki. Pisze, że założeń tych nie da się naukowo uzasadnić, gdyż wszelkie badania naukowe już je zakładają. Przyjmuje się je w sposób arbitralny. Podstawą epistemicznego układu odniesienia nowożytnej i współczesnej nauki jest, twierdzi Jodkowski, naturalizm metodologiczny, w ramach którego wyklucza się nadnaturalne wyjaśnianie zjawisk ${ }^{22}$.

Przywołując kolejno koncepcje Flecka, Crombiego, Hackinga, Amsterdamskiego i Jodkowskiego, gdzie analizuje się wpływ pozanaukowych przesłanek na rozwój nauki, chciałbym podkreślić, że w mojej opinii consensus omnium, w ramach którego ten rozwój się dokonuje, choć nie jest wyrazem niezmiennej racjonalności natury ludzkiej wiedzy, to podstawową rolę odgrywa w nim względnie trwały zespół myśli i wartości składających się na to, co można by określić mianem naukowej tradycji badawczej. To właśnie ta tradycja, głównie ze względu na swój krytyczny charakter, z jednej strony dostarcza wewnętrznych inspiracji do poszukiwania nowych rozwiązań poznawczych, z drugiej zaś pozostaje podstawą uniwersalizacji i standaryzacji tego, co w niej nowe i odkrywcze.

Głównym celem podjętej przeze mnie próby obrony obecności kantyzmu w badaniach z zakresu współczesnej filozofii nauki jest zniuansowanie jednoznacznie brzmiącego przekonania autora Struktury rewolucji relatywistycznej i kwantowej $w$ fizyce, że ów kantyzm przeszedł do lamusa i nie wywiera wpływu na pojmowanie natury wiedzy ludzkiej. Podejmując tego rodzaju próby, należy oczywiście pamiętać, że teorię relatywistyczną traktuje się dziś powszechnie jako zakwestionowanie estetyki transcendentalnej, a mechanikę kwantową - jako przykład obalenia analityki transcendentalnej.

\section{Bibliografia}

Amsterdamski S., Filozofia nauki i socjologia wiedzy, [w:] Racjonalność współczesności, H. Kozakiewicz, E. Mokrzycki, M. Siemek (red.), Warszawa 1992, s. 319-334. Amsterdamski S., Między historia a metoda, Warszawa 1983.

Blackburn S., Oksfordzki słownik filozoficzny, tłum. C. Cieśliński et al., Warszawa 2004.

Dummett M., Logiczna podstawa metafizyki, tłum. W. Sady, Warszawa 1998.

20 S. Amsterdamski, Między historia a metoda, Warszawa 1983, s. 36.

21 Ibidem, s. 40.

22 K. Jodkowski, Epistemiczne układy odniesienia a „warunek Jodkowskiego”, [w:] Filozoficzne i naukowo-przyrodnicze elementy obrazu świata 7, A. Latawiec, G. Bugajak (red.), Warszawa 2008, s. $108-123$. 
Hacking I., Language, truth, and reason, [w:] idem, Historical Ontology, Cambridge-London 2002, s. 159-177.

Hacking I., "Style" for historians and philosophers, [w:] idem, Historical Ontology, Cambridge-London 2002, s. 178-199.

Horwich P., Three Forms of Realism, „Synthese” 51 (1982), s. 121-202.

Jodkowski K., Epistemiczne układy odniesienia a „warunek Jodkowskiego”, [w] Filozoficzne i naukowo-przyrodnicze elementy obrazu świata, A. Latawiec, G. Bugajak (red.), Warszawa 2008, s. 108-123.

Nagel E., Struktura nauki, tłum. J. Giedymin et al., Warszawa 1961.

Sady W., Struktura rewolucji relatywistycznej i kwantowej w fizyce, Kraków 2020.

Szubka T., Antyrealizm semantyczny. Studium analityczne, Lublin 2001.

Woleński J., Metamatematyka a epistemologia, Warszawa 1993. 